\section{Acute respiratory infections in children}

\section{Infecções respiratórias agudas em crianças}

Charles Anthony Hart 1

Luis E. Cuevas2

1 Division of Medical Microbiology. School of Infection and Host. Defence.University of Liverpool. Duncan Building. Daulby Street. Liverpool, L69 3 GA,U.K. Phone: 44151706 4381; Fax: 44151 706 5805. E-mail: cahmm@liv.ac.uk

2 Liverpool School of Tropical Medicine. Liverpool, UK

\begin{abstract}
Acute respiratory infections (ARI) are the leading cause of mortality in children under five years of age worldwide and most of these deaths are due to bronchiolitis and pneumonia. Recent evidence from studies using genome detection systems such as polymerase chain reaction or micro-array technology show that, in most cases, these deaths are caused or precipitated by viruses. In this paper, the definitions of upper and lower respiratory tract infections are reviewed. The principal signs of disease severity and the burden of viruses as causes of ARI are described. The prominent role of Respiratory Syncytial Virus is stressed, with data from epidemiological and clinical studies. Other important viral pathogens, such as Human Metapneumovirus, Human coronaviruses and Influenza are examined. The role of newly described viruses, such as bocavirus, is also discussed. The impact of HIV/AIDS in ARI burden and presentation assessed and the weight of Pneumocystis jiroveci and Mycobacterium tuberculosis infections is recognized. It is concluded that there is an urgent need to improve diagnostics, therapeutics and vaccines, as well as macro and micronutrient intake of children of the world, particularly in developing countries.
\end{abstract}

Key words Acute respiratory infections, Children, Viruses

\section{Resumo}

As infecções respiratórias agudas (IRA) são as principais causas da40 mortalidade mundial em crianças menores de cinco anos de idade e a maioria dessas mortes são próprias da bronquiolite e pneumonia. Recentes evidências de estudos usando sistemas de detecção no genoma tais como reação em cadeia da polimerase ou tecnologia de microarrays mostram que, na maioria dos casos, essas mortes são causadas ou precipitadas por vírus. Neste artigo, as definições das infecções dos tratos respiratórios superior e inferior são revisadas. Os principais sinais da gravidade da doença e a carga viral como causas da IRA estão descritas. $O$ papel proeminente do vírus sincicial respiratório é enfatizado, com dados de estudos clínicos e epidemiológicos. Outros importantes patógenos virais, tais como o metapneumovírus humano, o coronavírus humano e influenza são examinados. $O$ papel dos vírus recentemente descritos tais como o bocavírus, é também discutido. $O$ impacto do HIV/AIDS na apresentação e ônus da IRA é avaliado e a sobrecarga das infecções de Pneumocystis jiroveci e Mycobacterium tuberculosis é reconhecidas. Conclui-se que há uma necessidade urgente de melhorar o diagnóstico, a terapêutica e as vacinas, bem como a ingestão de macro e micronutrientes das crianças do mundo, parti-cularmente aquelas de países em desenvolvimento.

Palavras-chave Infecções respiratórias agudas, Crianças, Vírus 


\section{Introduction}

Acute respiratory infections (ARI) are the leading cause of mortality in children under five years of age worldwide. Over the period 2000 to 2003 it is estimated that each year there are 10.6 million deaths in children under five years. ${ }^{1}$ Four communicable diseases, (malaria, pneumonia, diarrhoeal disease and measles) accounted for $54 \%$ of these deaths and ARI alone for just over 2 million deaths (19\%). Most of these deaths are due to bronchiolitis and pneumonia. ${ }^{2}$ In most cases these are caused or precipitated by viruses. However it is only recently with the advent of genome detection systems such as polymerase chain reaction or micro-array technology that we are gaining a better insight into their impact.

ARI describes all infections of the respiratory tract both upper (URI) and lower (ALRI). In fact most respiratory viruses infect throughout the respiratory tract but do not necessarily always produce clinical manifestation of ALRI. For this to happen a number of other factors need to be present including environmental, (e.g. air-pollution from indoor fires or cigarettes, humidity), family circumstances (poverty, access to medical care, birth order, overcrowding) and medical circumstances (malnutrition, HIV/AIDS, prematurity, measles, chronic lung disease, diarrhoeal disease, malaria, micronutrient deficiency, e.g. vitamin A).

It is estimated that in the first two years of life each child experiences 8-9 episodes of URI each year. However progression from URI to ALRI occurs much more frequently in children in developing countries. ALRI is defined as any infection that affects the airways below the epiglottis and includes acute laryngitis, tracheitis, bronchitis and bronchiolitis and lung infections such as pneumonia, tuberculosis and empyema. There are at least two major ways to arrive at a clinical case definition ALRI. The method chosen can alter estimates of disease burden. ${ }^{3}$ The most widely used definition is based on pioneering work by Shann and colleagues in Papua/New Guinea, ${ }^{4}$ and was promulgated by the WHO. It assesses three principal signs to determine severity namely rapidity of breathing, chest indrawing and inability to feed. From this disease is classified as mild, moderate or severe and this determines therapeutic interventions (Table 1). It has been subsequently modified to give different thresholds for tachypnoea. Thus in children $\leq 2$ months the threshold is 60 breaths/minute (bpm), in those 2-11 months it is $50 \mathrm{bpm}$ and in those $1-4$ yrs is $40 \mathrm{bpm}$. This greatly improves the sensitivity of case identification but does decrease specificity. ${ }^{3}$ The second route is to base diagnosis on the individual paediatrician's experience and acumen using chest auscultation. However use of chest auscultation tends to decrease ALRI incidence estimates.5 A further complication is the ability to measure oxygen saturations $\left(\mathrm{pO}_{2}\right)$ with portable and relatively cheap pulse oximeters. This should improve our ability to grade disease severity but again it must be remembered that the cut-off for poor oxygen saturation will vary with altitude.

The most recent median global estimate of the incidence of pneumonia among children under $5 \mathrm{yr}$ is 0.28 episodes per child year (e/cy) with a $25 \%$ to $75 \%$ interquartile range of $0.21-0.71$ e/cy. 5 This equates to around 150.7 million new cases of pneumonia each year. In this study 5 the definition of cli-

Table 1

\begin{tabular}{lll}
\hline World Health Organization Guidelines for Assessment and Management of Acute Lower Respiratory Infections (ALRI). \\
\hline Disease Severity & \multicolumn{1}{l}{ Clinical Features } & Management \\
\hline Mild & $\begin{array}{l}\text { Blocked or runny nose with } \\
\text { cough, no tachypnoea }(<50 \mathrm{bpm}) \\
\text { no chest indrawing, sore throat, } \\
\text { ear discharge. }\end{array}$ & Home treatment, supportive therapy \\
Moderate & $\begin{array}{l}\text { Cough and tachypnoea but no } \\
\text { chest indrawing. }\end{array}$ & $\begin{array}{l}\text { Home treatment with antimicrobials } \\
\text { and supportive therapy }\end{array}$ \\
Severe & $\begin{array}{l}\text { Cough and chest indrawing, } \\
\text { cough and inability to feed or } \\
\text { stridor at rest. }\end{array}$ & Hospital referral \\
\hline
\end{tabular}

$\mathrm{bpm}=$ breaths per minute 


\begin{tabular}{|c|c|c|}
\hline Viruses & Bacteria & Other \\
\hline \multicolumn{3}{|l|}{ RNA Viruses } \\
\hline Coronaviruses & Streptococcus pneumoniae & Pneumocystis jiroveci \\
\hline Enterovirusest & Haemophilus influenzae & Plasmodium \\
\hline \multicolumn{3}{|l|}{ falciparumt } \\
\hline \multirow[t]{2}{*}{ Human metapneumovirus } & Staphylococcus aureus & \\
\hline & Moraxella catarrhalis & \\
\hline Influenza virus A, B, C & Bordetella pertussis & \\
\hline Measles & Mycobacterium tuberculosis* & \\
\hline Parainfluenza virus & Mycoplasma pneumoniae & \\
\hline Respiratory syncytial virus & Chlamydia trachomatis & \\
\hline \multirow[t]{2}{*}{ Rhinoviruses } & Chlamydophilia pneumoniae & \\
\hline & Chlamydophila psittacit & \\
\hline \multirow[t]{2}{*}{ DNA Viruses } & Coxiella burnettit & \\
\hline & Legionella pneumophilat & \\
\hline Adenovirus & Klebsiella pneumoniaet & \\
\hline Bocavirus & Non-typhoidal salmonellae & \\
\hline \multicolumn{3}{|l|}{ Cytomegalovirus* } \\
\hline \multicolumn{3}{|l|}{ Herpes simplex virus* $\dagger$} \\
\hline Torquetenovirus & & \\
\hline
\end{tabular}

† rare cause

* particular in HIV infections

nical pneumonia encompassed those with signs of pneumonia which also included those with bronchiolitis. The major bacterial causes of pneumonia are Streptococcus pneumoniae and Haemophilus influenzae. The inclusion of new capsular polysaccharide conjugate vaccines in the Expanded Program of Immunization should decrease the disease burden of pneumonia due to these pathogens. However there is a large and increasing number of other pathogens (Table 2) that can cause clinical pneumonia or ARLI and there are very few specific vaccines available.

\section{Viruses and ALRI}

In most surveys of the aetiology of ALRI in children where appropriate diagnostic methods have been used, viruses are the major aetiological agents. However it is also clear that HIV/AIDS has also greatly altered both the range of pathogens and disease manifestations, for example tuberculosis is usually considered to be a cause of chronic rather than acute chest infection. This has been altered by HIV/AIDS. However there is no doubt that even during the AIDS era respiratory syncytial virus is the major pathogen of childhood ALRI.

\section{Respiratory Syncytial Virus (RSV)}

RSV is undoubtedly the major cause of acute upper and lower respiratory tract infection worldwide and of bronchiolitis and pneumonia in children under 5 yr. RSV is an enveloped single stranded negative sense RNA virus with a helical nucleocapsid which is surrounded by a lipid envelope. On the surface of the lipid envelope is an array of two glycoprotein spikes, the G- and F- proteins (Figure 1). These are involved in attachment to and penetration into the host cell. They are highly immunogenic but immunity to virus is not strong perhaps because the two glycoproteins can vary tremendously. Indeed it is probable that each of us is infected by RSV every year. RSV has a worldwide distribution. In temperate countries RSV has a strong seasonal pattern with large peaks in the winter months. The onset of the season varies, for example, in the northern hemisphere from as early as September or as late as March. In tropical countries infections tend to peak in the rainy season. Studies from urban populations indicate that RSV infection severe enough to require hospitalization are predominantly in those aged under 12 months with a peak in the 2-6 month olds. In the USA in 1996 the hospitalization rate of infan- 
tile RSV infection was 31.2/1000 more than double that found in 1980, and resulted in 95 deaths each year. ${ }^{6}$ In the U.K. it is estimated that $25 / 1000$ infants are admitted to hospital with bronchiolitis and $3 \%$ of these are sufficiently ill to require admission to ICU. By 18 months of age $87 \%$ of children will have been infected by RSV and all by three years. Subsequent infections with RSV do not usually cause bronchiolitis unless there are predisposing factors such as broncho-pulmonary dysplasia. However, RSV does re-infect throughout an individual's lifetime most often causing sore throat and upper respiratory infections. However, there is now increasing evidence that RSV causes serious infection in the elderly. ${ }^{7}$ Transmission is by aerosol droplets or perhaps more importantly by transfer on hands. Nosocomial transmission is not uncommon especially in the RSV season when large numbers of children are admitted to hospital. Wearing gowns and gloves has been shown to decrease nosocomial transmission.

RSV can be subdivided into two major groups A and $\mathrm{B}$. However even within the groups there is tremendous variability especially in the surface glycoproteins $\mathrm{F}$ and $\mathrm{G}$. This may be a mechanism by which the virus escapes specific immune defences. As yet there is no vaccine available to prevent RSV infection, although a number of candidate vaccines are showing promise in Phase I studies. There is no specific antiviral therapy. Ribavirin which is effective in vitro appears to do little to modify the disease perhaps because its manifestation is related to an excessive innate immune response. Giving respiratory syncytial virus immune globulin to at risk infants (e.g. with broncho-pulmonary dysplasia) has been shown to be of benefit.

\section{Human Metapneumovirus (HMPV)}

\section{Figure 1}

A cartoon showing the structure of respiratory syncytial virus.

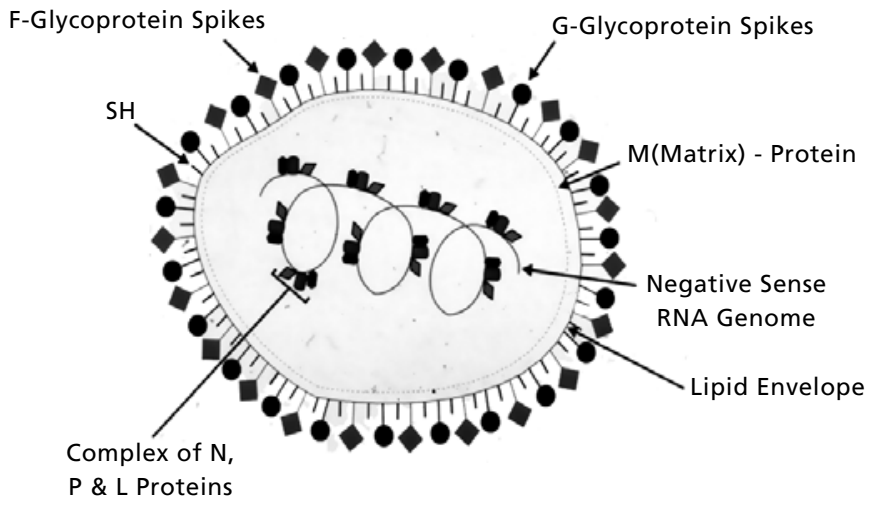

This is a newly described human virus being first reported as a cause of ARI among Dutch infants in 2001.8 There is no doubt that it has been in circulation for many years, so not new but undiscovered. It is an enveloped single stranded negative sense enveloped RNA virus (Figure 2) related to RSV. It is responsible for $5-15 \%$ of cases of ARI in children but like RSV appears to re-infect individuals throughout their lifetime. Although it can produce severe disease, it usually is less severe than RSV. There is some evidence that dual RSV/HMPV infection is more severe. ${ }^{9}$ HMPV infections are also seasonal. In some seasons they overlap with the RSV season but in others they do not. ${ }^{10} \mathrm{HMPV}$ can also be a cause of severe infection in the elderly and of exacerbations of chronic bronchitis. 11 There is no specific antiviral chemotherapy nor is there a vaccine.

\section{Figure 2}

A thin section electronmicrograph showing human metapneumovirus particles budding from the respiratory epithelium of a child with fatal acute respiratory infections (ARI).

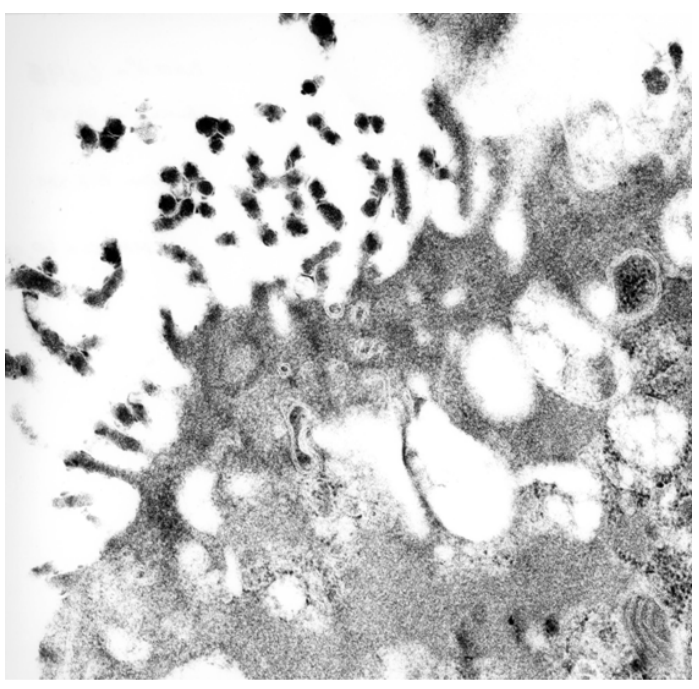

\section{Human Coronavirus (HCOV)}

Human coronaviruses ( $\mathrm{HCoV}$ ) were first described in the 1960's and were predominantly associated with mild to moderate upper respiratory tract infections. They are enveloped helical viruses with a single stranded positive sense genome. They are named for the club-shaped glycoprotein spikes protruding from the envelope surface that give the appearance of the corona around an eclipse (Figure 
3). Until recently there were two prototype strains (HCoV-229E and HCoV-OC43) which belong to genogroups 1 and 2 respectively. However in 2003 a brand new coronavirus was found to be responsible for an outbreak of severe acute respiratory syndrome (SARS). ${ }^{12}$ Although the first cases were found in Guangdong, China it eventually affected 30 countries on five continents with over 8400 cases and 920 deaths. It is a zoonotic agent transmitted to humans by other vertebrate animals but with onward personto-person transmission. Thus far SARSCoV has been detected in palm civets, dog raccoons and even bats. It appears that those in contact with palm civets and dog raccoons in live animal markets or restaurants where they were served were infected first. It then spread person-to-person. Although cases of SARS in persons exposed in laboratories have occurred since the major outbreak, extensive outbreaks have not arisen since 2003. The genome of SARSCoV has been fully sequenced and it was found to be different from all other genogroups described previously. It is now assigned to its own genogroup 4.

Figure 3

A negative stain electronmicrograph of a coronavirus particle.

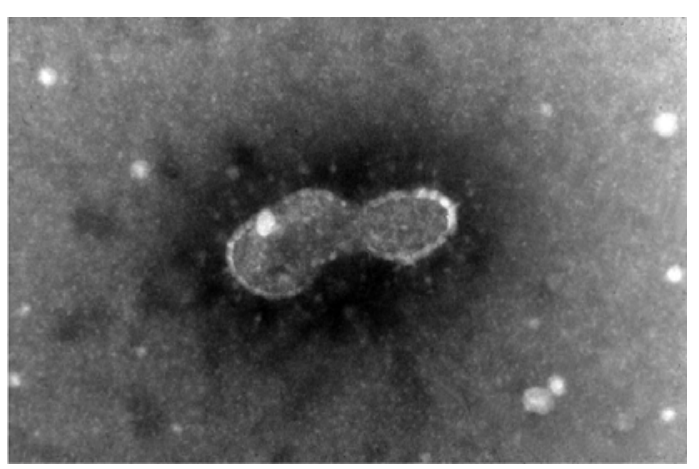

Disease appears to be mediated by activation of the innate and adaptive immune systems as fatal disease occurs when viral loads are waning and antibody appears. ${ }^{13}$ Infection in children is usually far less severe than in adults.

SARS stimulated further research on coronaviruses and to date two new human coronaviruses HKU114 and NL6315 have been found. HCoV-NL63 is in genogroup 1 and causes both upper and lower respiratory tract infections but especially in children. It is likely to have a worldwide distribution as cases have been detected in North America, Europe, Japan and China. HCoV-HKU1 was first detected in Hong
Kong but cases have been detected in Australia and Canada. It has a similar disease spectrum to $\mathrm{HCoV}$ NL63 but is in genogroup 2 .

\section{Influenza Viruses}

Influenza viruses are in the Myxovirus family and there are three major groups A, B and C. All are enveloped with a helical nucleocapsid surrounding a segmented, negative sense RNA genome (Figure 4). Although group B influenza viruses can cause severe disease, group A viruses are especially important because of their ability to cause both epidemics of ARI each winter and pandemics every 10-30 years when the whole world is susceptible to infection with a new strain of the virus. The virus is able to change its antigenicity particularly on the haemagglutinin or H-glycoprotein spikes (which mediate attachment to and penetration inside host cells) and the neuraminidase or $\mathrm{N}$-glycoprotein spikes (which cut newly synthesised virus free of host cells. There

Figure 4

A negative stain electronmicrograph of influenza A virus.

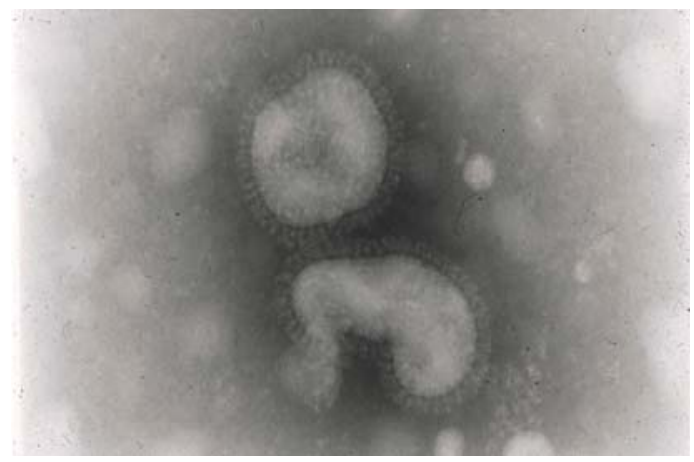

are two mechanisms by which the virus alters its antigenic nature to escape host immunity, namely antigenic drift and antigenic shift. Antigenic shift is a slow change by mutation. The viral RNA polymerase is sloppy and keeps putting in the wrong bases when copying the viral genome. There is no proof-reading mechanism so the changes are not corrected. Thus there is a slow accumulation of point mutations which changes the viral proteins structure. The estimated rate of change in the amino acids of the haemagglutinin glycoprotein is for example around $1 \%$ per year. Eventually its structure will have changed sufficiently that immunity gained 
when a patient had influenza four or five years previously can no longer recognise epitopes on the mutated virus. Antigenic drift is responsible for the epidemics seen in a proportion of the population each winter season.

The major change in influenza A virus is termed antigenic shift. This involves recombination when two or more influenza A viruses simultaneously infect the same cell. The genome of influenza A comprises eight segments and as the viruses are replicating they assemble containing different mixtures of the eight genomic segments, thus generating "new" viruses. This recombination occurs most frequently in passerine birds and migratory water fowl, which are normally unaffected. Such avian viruses are not well-adapted to human hosts. For example birds have higher body temperatures and the avian viral RNA polymerase works better at $40-42^{\circ} \mathrm{C}$, in addition their epithelial cells have slightly different receptor to those of humans. One plausible hypothesis is that the avian viruses have to be "humanized" by mutation and this involves passage through pigs. Once this happens a pandemic arises as the "new" virus has not infected humans previously. Currently there are $16 \mathrm{H}$ - and $9 \mathrm{~N}$-known types of influenza A virus but only H1N1, H2N2 and $\mathrm{H} 3 \mathrm{~N} 2$ have caused pandemic influenza in humans. Birds are infectable with all known strains of influenza A virus. The pandemic cycles appear to run H1 then H2 and then H3. Thus "Spanish flu" in 1919 was due to H1N1. In 1958, H2N2 caused the next pandemic (Asian flu) and H1N1 disappeared from circulation. In 1968, H3N2 caused Hong Kong Flu and H2N2 disappeared from circulation. Finally in 1977 Red Flu due to H1N1 appeared and at present both $\mathrm{H} 1 \mathrm{~N} 1$ and $\mathrm{H} 3 \mathrm{~N} 2$ are co-circulating. We are now due for a new pandemic. However the pandemics do differ in severity. It is estimated that Spanish Flu affected $35-40 \%$ of the world's population and killed more people than were killed in the First World War. Red Flu was far less severe.

In 1997 a new strain of influenza A, H5N1 infected 18 people in Hong Kong and killed 6 of them. ${ }^{16}$ It was traced to birds which were asymptomatic and sold in the wet markets of Hong Kong. There was no onward human-to-human transmission. A cull of all poultry in Hong Kong stopped it temporarily. It has caused sporadic infections subsequently. In $2002 \mathrm{H} 5 \mathrm{~N} 1$ mutated (drifted) so that it became lethal to birds, and spread to many countries in South East Asia. It has now infected over 200 individuals with a $50 \%$ mortality rate, $(89 \%$ rate in those under 16yr). Currently H5N1 has spread across Asia and has reached Western Europe and Africa,
(Egypt and Nigeria), brought it is presumed, by migratory birds. Thus far it has behaved as a classic zoonosis, passing from bird to humans but with no onward human to human transmission.

There are two classes of antiviral drugs effected against influenza. These are amantidine which works at the initial phase of influenza replication and the neuraminidase inhibitors which prevent virus being released from the infected cell. Both work relatively well as prophylactic and therapeutic agents. To be effective they need to be given within $48 \mathrm{hr}$ of onset of disease. Their use is being compromised by antiviral resistance which for amantidine rose globally from $0.4 \%$ in $1994-5$ to $12.3 \%$ in $2003-4$ with $61 \%$ of resistant isolates coming from Asia. ${ }^{17}$ For the neuraminidase inhibitors resistance is less common but in one study resistant mutants were detected in $12 \%$ of those being treated. 18

Current vaccines (for H1N1 and H3N2) are most often sub-unit vaccines (the $\mathrm{H}$ and $\mathrm{N}$ spikes) and work well. Because the viruses are drifting, new variants are incorporated each year. There is an H5 vaccine available for poultry but it is not possible to make one for the next pandemic virus until we know its nature.

\section{Human Bocavirus}

Human bocavirus is a newly described cause of ARI. ${ }^{19}$ It is a member of the Parvoviridae with an unenveloped eicosahedral capsid enclosing a single stranded DNA genome (Figure 5). It is responsible for $5-15 \%$ of cases of ARI in children and has been found in Sweden and Australia. We have evidence for its circulation in Guatemala, Jordan 20 and Iran. Its full role in ARI is still to be determined.

\section{Figure 5}

A negative stain electronmicrograph of human bocavirus.

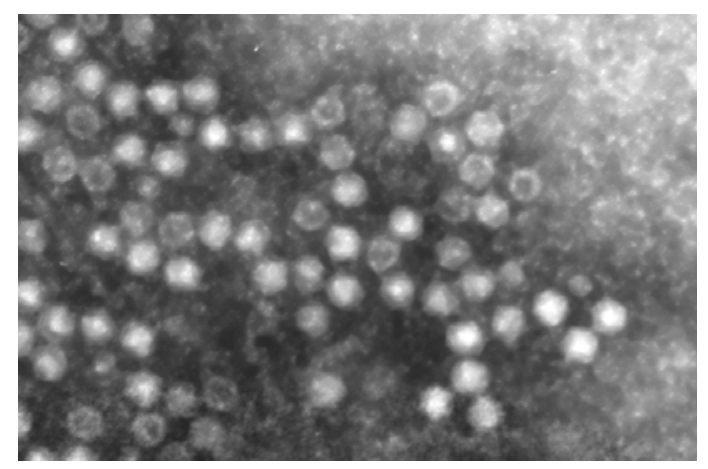




\section{Conclusions}

We have come a long way from studies in the 1960s and 1970s when an attributable cause of ARI was found in only 30-40\% of cases. An array of "new" viruses have emerged. In addition, old pathogens such as influenza are continually changing their spots and challenging our health care systems. Also the onset of the AIDS era has altered patterns of

\section{References}

1. Bryce J, Boschi-Pinto C, Shibuya K, Black RE. WHO estimates the causes of death in children. Lancet. 2005; 365 : $1147-52$.

2. Williams BG, Gouws E, Boschi-Pinto C, Bryce J, Dye C. Estimates of world-wide distribution of child deaths from acute respiratory infections. Lancet Infect Dis. 2002; 2: 2532.

3. Lanata CF, Rudan I, Boschi-Pinto C, Tomaskovic L, Cherian T, Weber M, Campbel H. Methodological and quality issues in epidemiological studies of acute lower respiratory infection in children in developing countries. Int J Epidemiol. 2004; 33: 1362-72.

4. Shann F, Hart K, Thomas D. Acute lower respiratory tract infections in children: possible criteria for selection of patients for antibiotic therapy and hospital admission. Bull WHO. 1984; 62: 749-53.

5. Rudan I, Tomaskovic L, Boschi-Pinto C, Campbell $\mathrm{H}$. Global estimates of the incidence of clinical pneumonia among children under five years of age. Bull WHO. 2004; 82: 895-903.

6. Shay DK, Holman RC, Roosevelt GE, Clarke MJ, Anderson LJ. Bronchiolitis-associated mortality and estimates of respiratory syncytial virus-associated deaths among US children, 1979-1997. J Infect Dis. 2001; 183: 16-22.

7. Falsey AK, Hennessey PA, Formica MA, Cox C, Walsh EE. Respiratory syncytial virus infection in elderly and high risk adults. N Engl J Med. 2005; 352: 1749-59.

8. van den Hoogen BG, de Jong JC, Groen J, Kuiken T, de Groot R, Fouchier RA, Osterhaus AD. A newly discovered human pneumovirus isolated from young children with respiratory disease. Nat Med. 2001; 7: 719-24.

9. Semple MG, Cowell A, Dove W, Greersill J, McNamara PS, Halphide C, Shears P, Smith RL, Hart CA. Dual infection of infants by human metapneumovirus and human respiratory virus is strongly associated with severe bronchiolitis. J Infect Dis. 2005; 19: 382-86.

10. Serafino RL, Gurgel RQ, Dove W, Hart CA, Cuevas LE. Respiratory syncytial virus and metapneumovirus in children over two seasons with a high incidence of respiratory infections in Brazil. Ann Trop Paediatr. 2004; 24: 213-17.

11. Martinello RA, Esper F, Weibel C, Ferguson D, Landry ML, Kahn JS. Human metapneumovirus and exacerbation of chronic obstructive pulmonary disease. J Infect. 2006; 53:

Submitted on October 24, 2006

Final version on January 10, 2007

Aproved on January 31, 2007.
ARI.21 Pneumocystis jiroveci has assumed great importance in childhood ARI 22 and Mycobacterium tuberculosis has become a cause of acute pneumonia. There is an urgent need to improve diagnostics, therapeutics and vaccines as well as to improve macro and micronutrient intake for the health needs of children of the world particularly in developing countries.

248-54.

12. Pieris JSM, Lai ST, Poon LLM, Guam Y, Yam LYC, Lim W, Nicholls J, Yee WKS, Yan WW, Cheung MT, Cheng VCC, Chan KH, Tsang DNC, Yung RWR, Ng TK, Yuen $\mathrm{KY}$, and members of the SARS study group. Coronavirus as a possible cause of severe acute respiratory syndrome. Lancet. 2003; 361: 1615-17.

13. Poon LLM, Guan Y, Nicholls JM, Yuen KY, Pieris JSM. The aetiology, origins and diagnosis of severe acute respiratory sundrome. Lancet Infect Dis. 2004, 4: 663-71.

14. Woo PCY, Lau SKP, Chu C-M, Chan KH, Tsoi HW, Huang Y, Wong BH, Poon RW, Cai JJ, Luk WK, Poon LL, Wong SS, Guan Y, Peiris JS, Yuen KY. Characterization and complete genome sequence of a novel coronavirus, coronavirus HKU-1 from patients with pneumonia. J Virol. 2005; 79: 884-95.

15. van der Hoek L, Pyrc K, Jebbink MF, Vermeulen -Oost W, Berkhout RJ, Wolthers KC, Wertheim-vam, Dillen PM, Kaandorp J, Spaargarem J Berkhout B. Identification of a human coronavirus. Nat Med. 2004; 10: 368-371.

16. Webster RG, Pieris M, Chen H, Guan Y. H5N1 outbreaks and enzootic influenza. Emerg Infect Dis. 2006; 12: 3-8.

17. Bright RA, Medina M-J, Xu X, Perez - Orong G, Wallis TR, Davis XM, Povinelli L, Cox NJ, Klimov AI. Incidence of amantidine resistance among influenza A (H3N2) viruses isolated worldwide from 1995-2005: a cause for concern. Lancet. 2005; 366: 1175-81

18. de Jong MD, Tranh TT, Khanh TW, Tran TT, Truong HK, Vo MH, Smith GJ, Nguyen VC, Bach VC, Phar TQ, Do QH, Guan Y, Peiris JS, Tran TH, Farrar J. Oseltamivir resistance during treatment of influenza A (H5N1) infection. N Engl J Med. 2005; 353: 2667-72.

19. Allander T, Tammi MT, Erikson M, Bjerkner A, Tiveljung Lindell A, Andersson B. Cloning of a human parvovirus by molecular screening of respiratory tract samples. Proc Natl Acad Sci USA. 2005; 102: 12891-96.

20. Kaplan NM, Dove W, Abu-Zeid AF, Shamoon HE, AbdEldayem SA, Hart CA. Human bocavirus infection among children, Jordan. Emerg Infect Dis. 2006; 12: 1418-20.

21. Zar HJ. Pneumonia in HIV-infected HIV-uninfected children in developing countries: epidemiology, clinical features and management. Curr Opin Pulmon Med. 2004; 10: $176-82$.

22. Graham SM, Mtitimila EI, Kamanga HS, Walsh AL, Hart CA, Molyneux ME. Clinical presentation and outcome of Pneumocystis carinii pneumonia in Malawian children. Lancet. 2000; 355: 369-73. 